In a room on the floor above there is a special exhibition of a large number of photographs, which is being constantly increased by new additions. They consist of photographs of all the ancient instruments copied from engravings of the period; and all the foreign instruments in present use, taken from nature. There are also drawings representing the principal observatories in the world.

Such is the commencement of the astronomical museum of the Paris Observatory. It will be completed by organising a second circular room resembling that which we have just rapidly passed under review. This new room will be adorned with portraits of the most illustrious of foreign astronomers :--Newton, Galileo, Tycho-Brahe, Kepler, Copernicus, Herschel, Bradley, and others. It will also contain a special exhibition of large astronomical instruments; notably a quadrant of Lalande's, a sextant of Lacaille's, a quadrant of Langlois' which was used by the North Pole Committee, and a meridian telescope of Delambre.

It would be useful to bring together in the Paris Observatory those instruments which are scattered here and there in various other national institutions, so as to complete a collection already so rich in valuable objects. The directors will also gratefully accept of any bequests that may be addressed to them from private individuals, as was done by Mme. Laugier with reference to the instruments of Arago and Delambre which she had in her possession.

After our survey of the new Astronomical Museum, it now remains to say a few words regarding the extension of the observatory, which is about to be made by annexing the ground on the Boulevard Arago (Fig. I). This waste land contains a superficies of at least 9000 metres, and when the ditch which at present divides it from the $\mathrm{Ob}$ servatory garden is filled up, it will be united to the rest of the institution without any separation. On these grounds will be erected the great $75 \mathrm{~m}$. telescope, the arrangements for which are already well advanced; also the equatorial presented by M. Bischoffsheim, the circle of Fortin, which long rendered excellent service, and was dismounted in 1862 to make room for the the great meridian-circle, and several instruments for the special use of the pupils.

The plan which we give above (Fig. I), from official documents, shows what the Paris Observatory will be as a whole when the projected improvements are completed.

We regret that the works are being so slowly carried on, notwithstanding the praiseworthy energy evinced by the directors of the Observatory. A ditch to be filled in, a garden to be laid out, a few buildings to be erected, all amount to but very little. But before the masons cut a stone or the gardeners trace an alley there is a path to be traversed which is not exactly the shortest or quickest, viz. that of administrative and official routine.

\section{ACHILLE DELESSE}

WE regret to have to record the death of this eminent geologist, which took place, after a long illness, on March 24. Delesse was born at Metz, and was educated at the lyceum of that town, afterwards proceeding, at the age of twenty, to the École Polytechnique at Paris. He was a diligent and successful student, and in 1839 took his degree as a mining engineer. $\mathrm{He}$ then travelled for some time through his own country, in Germany, Poland, and the British Islands, and in 1845 was appointed Professor of Geology and Mineralogy at Besançon, where he also practised as a mining engineer. It was during his residence here that he wrote his "Notice sur les Characteres de l'Arkose dans les Vosges," and his "Memoire sur la Constitution minéralogique et chimique des Roches de Vosges," both of which works appeared in 1847 . After a stay of five years at Besançon
Delesse returned to Paris, where he was employed as a mining engineer, and was especially engaged in superintending the quarrying operations about the city for nearly eighteen years. In 1855 he prepared the report on building materials in connection with the Exposition Universelle of that year in Paris. In 1864 he was nominated Professor of Agriculture, Drainage, and Irrigation in the École des Mines. Delesse's earliest researches were directed to pure mineralogy, and he paid great attention to the subjects of pseudomorphs and the association of minerals, and this led him to study the question of the metamorphism of rocks. The outcome of this perioc" cf study was his well-known work, "Recherches sur l'Origine des Roches," published in 1865 , in which he argued ably and forcibly in favour of the view that crystalline rocks owe many of their characters to the action of superheated water, and are not produced by simple dry fusion. This important work of Delesse has exercised a marked and very beneficial influence on the progress of petrographical science, and its originality and value were at once recognised by the most advanced thinkers of the time. Already in 1858 Delesse had published two of his valuable maps, namely, the "Carte géologique soutteraine de la Ville de Paris" and the "Carte hydrologique de la Ville de Paris," and his subsequent studies came to be especially directed into the channels of inquiry which were associated with the professorship that he had created and so ably filled. In 1868 appeared his work on the Rainfall of France, and other memoirs treating of the agricultural bearings of geology were produced about the same period.

The war of 1870 caused an interruption in the scientific labours of Delesse, and we find him at this period superintending the construction of cartridges in the departments. But in 1878 he was appointed an InspectorGeneral of Mines, and the south-east of France was assigned to him as his district. During the last twenty years Delesse has issued, in conjunction with MM. Langel and de Lapparent, a series of annual volumes entitled "Revue de Géologie," a work of such value that we regret to hear that it is to be discontinued in the future. Delesse received many honours in recognition of his valuable labours. He was an officer of the Legion of Honour, and filled the post of President of the Geological Society of France. As long ago as 1859 he was elected a Foreign Member of our own Geological Society. He was also for two years President of the French Geological Society, and he occupied the chair during the International Congress of that Society in 1875 . In 1879 Delesse was elected a Member of the Academy of Sciences. In Delesse France has lost one of her most distinguished and widely-known scientific men.

\section{PROFESSOR HELMHOLTZ'S FARADAY LECTURE}

$\mathrm{N}$ Tuesday evening Prof. Helmholtz gave the Faraday Lecture of the Chemical Society at the Royal Institution. We have so recently (NATURE, vol. xv. p. 389) given a full account of the life and work of the eminent German worker in various departments of science, that it is unnecessary to go over the ground again. A very fair estimate of his position was given in a leading article in the Times of Saturday last; and we are glad to notice that the leading journal now is glad to draw attention to men of science whose work is deserving of public notice. The University of Cambridge did itself the honour of conferring upon Prof. Helmholtz the degree of LL.D. on Thursday last, on which occasion the public orator, Mr. Sandys, made the following elegant and appropriate speech :--

"Dignissime domine, domine Procancellarie, et tota Academia :

"Singularum quidem scientiarum terminos protulisse, 
plurimis concessum est; uni vero plurimarum fines extendisse raro contigit. Atqui hodie virum salutamus, qui rerum naturae regionem plusquam unam feliciter occupavit, qui primum physiologiae penetralia perscrutatus, deinde physicorum studiorum campo amplissimo potitus, ipsam denique mathematicorum arcem fortiter expugnavit, ex alia deinceps in aliam provinciam progressus, velut militum Romanorum ille maximus, 'victrices aquilas alium laturus in orbem.'

"Militarium medicorum ordini adhuc adscriptus, argumentum magnum intra unius libelli fines artiores complexus, ostendit vim illam, quae nonnunquam viva vocatur, in universa rerum natura esse conservatam, partes eius aliam ex alia posse generari, summam esse immutabilem. Quid huius ingenio excogitatas commemorem quaestiones illas hydrodynamicas, quid vortices illos qui scientiae mathematicae ad interiora pertinent? Illa vero magna opera, quorum in uno sensus audiendi clarissime explicatur, in altero videndi sensus pulcherrime illustratur, omnes, nisi fallor, aut vidistis ipsi, aut fama certe audivistis. Pulchrum est (uti hunc ipsum confitentem legimus), pulchrum profecto est, e scopulo quodam excelso late tumultuantem oceanum prospicere, fluctusque procul albescentes, modo breviores, modo longiores, oculis discernere : pulchrius autem in physiologiae templo intimo versatum, oculorum ipsorum structuram exquisitam introspicere, et, lucis legibus obscuris ordine lucido evolutis, fluctuantes luminis motus metiri variamque colorum venustatem explicare: omnium fortasse pulcherrimum, in iisdem arcanis morantem, undas illas aeris quas nulla nisi mentis acie contemplari possumus, inter sese audiendo distinguere; sonitus cuiusque, dum tremit vibratque, intervalla numerare; universam denique musices theoriam et mathematicis et physicis et physiologicis probavisse argumentis.

"Ille igitur qui tot provinciarum confinia lustravit, tot scientiarum fines propagavit, a nostra praesertim Academia, cuius alumni totiens ex eodem studiorum campo laureas reportarunt, ea qua par est reverentia hodie excipitur. Qui Academiae nostrae nemora, et iuventutis Academicae ludos et certamina iampridem admiratus est, idem fortasse severiora nostra studia quo melius noverit, eo benignius indies aestimabit. Vos certe, qui, talium virorum exemplar procul venerati, etiam nostras inter silvas verum quaeritis, quanquam hodie nemora illa nostra gravis umbra contristat, tamen inter ipsas lacrimas non sine gaudio virum magnum vidistis, quaque soletis benevolentia laudatum audivistis.

"Vobis igitur praesento Academiae Berolinensis Professorem illustrem, HERMANNUM LUDOVICUM FERDINANDUM HELMHOLTZ."

The Society of Telegraph Engineers are to give a conversazione in honour of the distinguished electrician at University College, Gower Street, on the evening of the IIth inst. The large library and entrance hall will be lit up by electric light, and it is hoped there will be a full display of all the recent novelties in electrical science.

As might have been expected, there was a distinguished audience on Tuesday $\epsilon$ vening to listen to Prof. Helmholtz at the Royal Institution. Prof. Roscoe, the President of the Chemical Society, in introducing the lecturer, made the following remarks:-

"Ladies and Gentlemen, Fellows of the Chemical Society-The cordial welcome which you have just given to Prof. Helmholtz shows me that he needs no formal introduction at my hands. His name is honoured wherever science is valued, and both his face and his voice are well remembered in this room. It may therefore suffice if I say that eminent as an anatomist, as a physiologist, as a physicist, and as a mathematician, we chemists are now about to claim him also as our own.

"Prof. Helmholtz, in the name of the Chemical Society, and on behalf of its Fellows here assembled, I beg to welcome you amongst us; I have the honour to present you with the Faraday Medal of the Society, and to request that you will favour us with your lecture, to which we shall all listen with pleasure and profit."

\section{The Faraday Lecture ${ }^{\mathrm{I}}$}

THE majority of Faraday's own researches were connected, directly or indirectly, with questions regarding the nature of electricity, and his most important and most renowned discoveries lay in this field. The facts which he has found are universally known. Nevertheless, the fundamental conceptions by which Faraday has been led to these much-admired discoveries have not been received with much consideration. His principal aim was to express in his rew conceptions only facts, with the least possible use of hypothetical substances and forces. This was really a progress in general scientific method, destined to purify science from the last remnants of metaphysics. Now that the mathematical interpretation of Faraday's conceptions regarding the nature of electric and magnetic force has been given by Clerk Maxwell, we see how great a degree of exactness and precision was really hidden behind his words, which to his contemporaries appeared so vague or obscure ; and it is astonishing in the highest degree to see what a large number of general theories, the methodical deduction of which requires the highest powers of mathematical analysis, he has found by a kind of intuition, with the security of instinct, without the help of a single mathematical formula.

The electrical researches of Faraday, although embracing a great number of apparently minute and disconnected questions, all of which he has treated with the same careful attention and conscientiousness, are really always aiming at two fundamental problems of natural philosophy, the one more regarding the nature of physical forces, or of forces working at a distance ; the other, in the same way, regarding chemical forces, or those which act from molecule to molecule, and the relation between these and the first.

The great fundamental problem which Faraday called up anew for discussion was the existence of forces working directly at a distance without any intervening medium. During the last and the beginning of the present century the model after the likeness of which nearly all physical theories had been formed was the force of gravitation acting between the sun, the planets, and their satellites. It is known how, with much caution and even reluctance, Sir Isaac Newton himself proposed his grand hypothesis, which was destined to become the first great and imposing example, illustrating the power of true scientific method.

But then came Oerstedt's discovery of the motions of magnets under the influence of electric currents. The force acting in these phenomena had a new and very singular character. It seemed as if it would drive a single isolated pole of a magnet in a circle around the wire conducting the current, on and on without end, never coming to rest. Faraday saw that a motion of this kind could not be produced by any force of attraction or repulsion, working from point to point. If the current is able to increase the velocity of the magnet, the magnet must react on the current. So he made the experiment, and discovered induced currents; be traced them out through all the various conditions under which they ought to appear. He concluded that somewhere in a part of the space traversed by magnetic force there exists a peculiar state of tension, and that every change of this tension produces electromotive force. This unknown hypothetical state he called provisionally th e electrotonic state, and he was occupied for years and years in

$$
\text { I Abstract prepared by the author. }
$$


finding out what was this electrotonic state. He discovered at first, in 1838 , the dielectric polarisation of electric insulators, subject to electric forces. Such bodies show, under the influence of electric forces, phenomena perfectly analogous to those exhibited by soft iron under the influence of the magnetic force. Eleven years later, in 1849 , he was able to demonstrate that all ponderable matter is magnetised under the influence of sufficiently intense magnetic force, and at the same time he discovered the phenomena of diamagnetism, which indicated that even space, devoid of all ponderable matter, is magnetisable; and now with quite a wonderful sagacity and intellectual precision Faraday performed in his brain the work of a great mathematician without using a single mathematical formula. He saw with his mind's eye that by these systems of tensions and pressures produced by the dielectric and magnetic polarisation of space which surrounds electrified bodies, magnets or wires conducting electric currents, all the phenomena of electro-static, magnetic, electro-magnetic attraction, repulsion, and induction could be explained, without recurring at all to forces acting directly at a distance. This was the part of his path where so few could follow him; perhaps a Clerk Maxwell, a second man of the same power and independence of intellect, was necessary to reconstruct in the normal methods of science the great building, the plan of which Faraday had conceived in his mind and attempted to make visible to his contemporaries.

Nevertheless the adherents of direct action at a distance have not yet ceased to search for solutions of the electromagnetic problem. The present development of science, however, shows, as I think, a state of things very favourable to the hope that Faraday's fundamental conceptions may in the immediate future receive general assent. His theory, indeed, is the only existing one which is at the same time in perfect harmony with the facts observed, and which at least does not lead into any contradiction against the general axioms of dynamics.

It is not at all necessary to accept any definite opinion about the ultimate nature of the agent which we call electricity.

Faraday himself avoided as much as he could giving any affirmative assertion regarding this problem, although he did not conceal his disinclination to believe in the existence of two opposite electric fluids.

For our own discussion of the electro-chemical phenomena, to which we shall turn now, I beg permission to use the language of the old dualistic theory, because we shall have to speak principally on relations of quantity.

I now turn to the second fundamental problem aimed at by Faraday, the connection between electric and chemical force. Already, before Faraday went to work, an elaborate electro-chemical theory had been established by the renowned Swedish chemist Berzelius, which formed the connecting-link of the great work of his life, the systematisation of the chemical knowledge of his time. His starting point was the series into which Volta had arranged the metals according to the electric tension which they exhibit after contact with each other. A fundamental point which Faraday's experiment contradicted was the supposition that the quantity of electricity collected in each atom was dependent on their mutual electro-chemical differences, which he considered as the cause of their apparently greater chemical affinity. But although the fundamental conceptions of Berzelius' theory have been forsaken, chemists have not ceased to speak of positive and negative constituents of a compound body. Nobody can overlook that such a contrast of qualities, as was expressed in Berzelius' theory, really exists, welldeveloped at the extremities, less evident in the middle terms of the series, playing an important part in all chemical actions, although often subordinated to other influences.
When Faraday began to study the phenomena of decomposition by the galvanic current, which of course were considered by Berzelius as one of the firmest supports of his theory, he put a very simple question, the first question indeed which every chemist speculating about electrolysis ought to have answered. He asked, What is the quantity of electrolytic decomposition if the same quantity of electricity is sent through several electrolytic cells? By this investigation he discovered that most important law, generally known under his name, but called by him the law of definite electrolytic action.

Faraday concluded from his experiments that a definite quantity of electricity cannot pass a voltametric cell containing acidulated water between electrodes of platinum without setting free at the negative electrode a corresponding definite amount of hydrogen, and at the positive electrode the equivalent quantity of oxygen, one atom of oxygen for every pair of atoms of hydrogen. If instead of hydrogen any other element capable of substituting hydrogen is separated from the electrolyte, this is done also in a quantity exactly equivalent to the quantity of hydrogen which would have been evolved by the same electric current.

Since that time our experimental methods and our knowledge of the laws of electrical phenomena have made enormous progress, and a great many obstacles have now been removed which entangled every one of Faraday's steps and obliged him to fight with the confused ideas and ill-applied theoretical conceptions of some of his contemporaries. We need not hesitate to say that the more experimental methods were refined, the more the exactness and generality of Faraday's law was confirmed.

In the beginning Berzelius and the adherents of Volta's original theory of galvanism, based on the effects of metallic contact, raised many objections against Faraday's law. By the combination of Nobili's astatic pairs of magnetic needles with Schweigger's multiplicator, a coil of copper wire with numerous circumvolutions, galvanometers became so delicate that the electro-chemical equivalent of the smaller currents they indicated was imperceptible for all chemical methods. With the newest galvanometers you can very well observe currents which would want to last a century before decomposing one milligram of water, the smallest quantity which is usually weighed on chemical balances. You see that if such a current lasts only some seconds or some minutes, there is not the slightest hope to discover its products of decomposition by chemical analysis. And even if it should last a long time the feeble quantities of hydrogen collected at the negative electrode can vanish, because they combine with the traces of atmospheric oxygen absorbed by the liquid. Under such conditions a feeble current may continue as long as you like without producing any visible trace of electrolysis, even not of galvanic polarisation, the appearance of which can be used as an indication of previous electrolysis. Galvanic polarisation, as you know, is an altered state of the metallic plates which have been used as electrodes during the decomposition of an electrolyte. Polarised electrodes, when connected by a galvanometer, give a current which they did not give before being polarised. By this current the plates are discharged again and returned to their original state of equality.

This depolarising current is indeed a most delicate means of discovering previous decomposition. I have really ascertained that under favourable conditions one can observe the polarisation produced during some seconds by a current which decomposes one milligram of water in a century.

Products of decomposition cannot appear at the electrodes without motions of the constituent molecules of the electrolyte throughout the whole length of the liquid. This subject has been studied very carefully and for a 
great number of liquids, by Prof. Hittorff, of Münster, and Prof. G. Wiedemann, of Leipsic.

Prof. F. Kohlrausch, of Würzburg, has brought to light the very important fact that in diluted solutions of salts, including hydrates of acids and hydrates of caustic alkalis, every atom under the influence of currents of the same density moves on with its own peculiar velocity, independently of other atoms moving at the same time in the same or in opposite directions. The total amount of chemical motion in every section of the fluid is represented by the sum of the equivalents of the cation gone forwards and of the anion gone backwards, in the same way as in the dualistic theory of electricity, and the total amount of electricity flowing through a section of the conductor corresponds to the sum of positive electricity going forwards and negative electricity going backwards.

This established, Faraday's law tells us that through each section of an electrolytic conductor we have always equivalent electrical and chemical motion. The same definite quantity of either positive or negative electricity moves always with each univalent ion, or with every unit of affinity of a multivalent ion, and accompanies it during all its motions through the interior of the electrolytic fluid. This we may call the electric charge of the atom.

Now the most startling result, perhaps, of Faraday's law is this: If we accept the hypothesis that the elementary substances are composed of atoms we cannot avoid concluding that electricity also, positive as well as negative, is divided into definite elementary portions, which behave like atoms of electricity. As long as it moves about on the electrolytic liquid each atom remains united with its electric equivalent or equivalents. At the surface of the electrodes decomposition can take place if there is sufficient electromotive power, and then the atoms give off their electric charges and become electrically neutral.

Now arises the question, Are all these relations between electricity and chemical combination limited to that class of bodies which we know as electrolytes? In order to produce a current of sufficient strength to collect enough of the products of decomposition without producing too much heat in the electrolyte, the substance which we try to decompose ought not to have too much resistance against the current. But this resistance may be very great, and the motion of the ions may be very slow, so slow indeed that we should need to allow it to go on for hundreds of years before we should be able to collect even traces of the products of decomposition; nevertheless all the essential attributes of the process of electrolysis could subsist. If you connect an electrified conductor with one of the electrodes of a cell filled with oil of turpentine, the other with the earth, you will find that the electricity of the conductor is discharged unmistakably more rapidly through the oil of turpentine than if you take it away and fill the cell only with air.

Also in this case we may observe polarisation of the electrodes as a symptom of previous electrolysis. Another sign of electrolytic conduction is that liquids brought between two different metals produce an electromotive force. This is never done by metals of equal temperature, or other conductors which, like metals, let electricity pass without being decomposed.

The same effect is also observed even with a great many rigid bodies, although we have very few solid bodies which allow us to observe this electrolytic conduction with the galvanometer, and even these only at temperatures near to their melting-point. It is nearly impossible to shelter the quadrants of a delicate electrometer against being charged by the insulating bodies by which they are supported.

In all the cases which I have quoted one might suspect that traces of humidity absorbed by the substance or adbering to their surface were the electrolytes. I show you therefore this little Daniell's cell, in which the porous septum has been substituted by a thin stratum of glass. Externally all is symmetrical at both poles; there is nothing in contact with the air but a closed surface of glass, through which two wires of platinum penetrate. The whole charges the electrometer exactly like a Daniell's cell of very great resistance, and this it would not do if the septum of glass did not behave like an electrolyte. All these facts show that electrolytic conduction is not at all limited to solutions of acids or salts.

Hitherto we have studied the motions of ponderable matter as well as of electricity, going on in an electrolyte. Let us study now the forces which are able to produce these motions. It has always appeared somewhat startling to everybody who knows the mighty power of chemical forces, the enormous quantity of heat and of mechanical work which they are able to produce, and who compares with it the exceedingly small electric attraction which the poles of a battery of two Daniell's cells show. Nevertheless this little apparatus is able to decompose water.

The quantity of electricity which can be conveyed by a very small quantity of hydrogen, when measured by its electrostatic forces, is exceedingly great. Faraday saw this, and has endeavoured in various ways to give at least an approximate determination. The most powerful batteries of Leyden jars, discharged through a voltameter, give scarcely any visible traces of gases. At present we can give definite numbers. The result is that the electricity of $\mathrm{I}$ mgrm. of water, separated and communicated to two balls, I kilometre distant, would produce an attraction between them, equal to the weight of 25,000 kilos.

The total force exerted by the attraction of an electrified body upon another charged with opposite electricity is always proportional to the quantity of electricity contained in the attracting as on the attracted body, and therefore even the feeble electric tension of two Daniell's elements acting through an electrolytic cell upon the enormous quantities of electricity with which the constituent ions of water are charged, is mighty enough to separate these elements and to keep them separated.

We now turn to investigate what motions of the ponderable molecules require the action of these forces. Let us begin with the case where the conducting liquid is surrounded everywhere by insulating bodies. Then no electricity can enter, none can go out through its surface, but positive electricity can be driven to one side, negative to the other, by the attracting and repelling forces of external electrified bodies. This process going on as well in every metallic conductor is called "electrostatic induction." Liquid conductors behave quite like metals under these conditions. Prof. Wüllner has proved that even our best insulators, exposed to electric forces for a long time, are charged at last quite in the same way as metals would be charged in an instant. There can be no doubt that even electromotive forces going down to less than ${ }_{1 \frac{1}{60}}$ Daniell produce perfect electrical equilibrium in the interior of an electrolytic liquid.

Another somewhat modified instance of the same effects is afforded by a voltametric cell containing two electrodes of platinum, which are connected with a Daniell's cell, the electromotive force of which is insufficient to decompose the electrolyte. Under this condition the ions carried to the electrodes cannot give off their electric charges. The whole apparatus behaves, as was first accentuated by Sir W. Thomson, like a condenser of enormous capacity.

Observing the polarising and depolarising currents in a cell containing two electrodes of platinum, hermetically sealed and freed of all air, we can observe these phenomena with the most feeble electromotive forces of $\frac{1}{1000}$ Daniell, and I found that down to this limit the capacity of the platinum surfaces proved to be constant. By taking greater surfaces of platinum I suppose it will be possible to reach a limit much lower than that. If any 
chemical force existed besides that of the electrical charges which could bind all the pairs of opposite ions together, and required any amount of work to be vanquished, an inferior limit to the electromotive forces ought to exist, which forces are able to attract the atoms to the electrodes and to charge these as condensers. No phenomenon indicating such a limit has as yet been discovered, and we must conclude therefore that no other force resists the motions of the ions through the interior of the liquid than the mutual attractions of their electric charges.

On the contrary, as soon as an ion is to be separated from its electrical charge we find that the electrical forces of the battery meet with a powerful resistance, the overpowering of which requires a good deal of work to be done. Usually the ions, losing their electric charges, are separated at the same time from the liquid; some of them are evolved as gases, others are deposited as rigid strata on the surface of the electrodes, like galvanoplastic copper. But the union of two constituents having powerful affinity to form a chemical compound, as you know very well, produces always a great amount of heat, and heat is equivalent to work. On the contrary, decomposition of the compound substances requires work, because it restores the energy of the chemical forces, which has been spent by the act of combination.

Metals uniting with oxygen or halogens produce heat in the same way, some of them, like potassium, sodium, zinc, even more heat than an equivalent quantity of hydrogen; less oxidisable metals, like copper, silver, platinum, less. We find therefore that heat is generated when zinc drives copper out of its combination with the compound halogen of sulphuric acid, as is the case in a Daniell's cell.

If a galvanic current passes through any conductor, a metallic wire, or an electrolytic fluid, it evolves heat. Mr. Prescott Joule was the first who proved experimentally that if no other work is done by the current the total amount of heat evolved in a galvanic circuit during a certain time is exactly equal to that which ought to have been generated by the chemical actions which bave been performed during that time. But this heat is not evolved at the surface of the electrodes, where these chemical actions take place, but is evolved in all the parts of the circuit, proportionally to the galvanic resistance of every part. From this it is evident that the heat evolved is an immediate effect, not of the chemical action, but of the galvanic current, and that the chemical work of the battery has been spent in producing only the electric action.

If we apply Faraday's law, a definite amount of electricity passing through the circuit corresponds to a definite amount of chemical decomposition going on in every electrolytic cell of the same circuit. According to the theory of electricity the work done by such a definite quantity of electricity which passes, producing a current, is proportionate to the electromotive force acting between both ends of the conductor. You see therefore that the electromotive force of a galvanic circuit must be, and is indeed, proportional to the heat generated by the sum of all the chemical actions going on in all the electrolytic cells during the passage of the same quantitity of electricity. In cells of the galvanic battery chemical forces are brought into action able to produce work; in cells in which decomposition is occurring work must be done against opposing chemical forces; the rest of the work done appears as heat evolved by the current, as far as it is not used up to produce motions of magnets or other equivalents of work.

Hitherto we have supposed that the ion with its electric charge is separated from the fluid. But the ponderable atoms can give off their electricity to the electrode, and remain in the liquid, being now electrically neutral. This makes almost no difference in the value of the electromotive force. For instance, if chlorine is separated at the anode, it will remain at first absorbed by the liquid; if the solution becomes saturated, or if we make a vacuum over the liquid, the gas will rise in bubbles. The electromotive force remains unaltered. The same may be observed with all the other gases. You see in this case that the change of electrically negative chlorine into neutral chlorine is the process which requires so great an amount of work, even if the ponderable matter of the atoms remains where it was.

The more the surface of the positive electrode is covered with negative atoms of the anion, and the negative with the positive ones of the cation, the more the attracting force of the electrodes exerted upon the ions of the liquid is diminished by this second stratum of opposite electricity covering them. On the contrary, the force with which the positive electricity of an atom of hydrogen is attracted towards the negatively charged metal increases in proportion as more negative electricity collects before it on the metal, and the more negative electricity collects behind it in the fluid.

Such is the mechanism by which electric force is concentrated and increased in its intensity to such a degree that it becomes able to overpower the mightiest chemical affinities we know of. If this can be done by a polarised surface, acting like a condenser, charged by a very moderate electromotive force, can the attractions between the enormous electric charges of anions and cations play an unimportant and indifferent part in chemical affinity?

You see, therefore, if we use the language of the dualistic theory and treat positive and negative electricities as two substances, the phenomena are the same as if equivalents of positive and negative electricity were attracted by different atoms, and perhaps also by the different values of affinity belonging to the same atom with different force. Potassium, sodium, zinc, must have strong attraction to a positive charge; oxygen, chlorine, bromine to a negative charge.

Faraday very often recurs to this to express his conviction that the forces termed chemical affinity and electricity are one and the same. I have endeavoured to give you a survey of the facts in their mutual connection, avoiding, as far as possible, introducing other hypotheses, except the atomic theory of modern chemistry. I think the facts leave no doubt that the very mightiest among the chemical forces are of electric origin. The atoms cling to their electric charges and the opposite electric charges cling to the atoms. But I don't suppose that other molecular forces are excluded, working directly from atom to atom. Several of our leading chemists have begun lately to distinguish two classes of compounds, molecular aggregates and typical compounds. The latter are united by atomic affinities, the former not. Electrolytes belong to the latter class.

If we conclude from the facts that every unit of affinity of every atom is charged always with one equivalent either of positive or of negative electricity, they can form compounds, being electrically neutral, only if every unit charged positively unites under the influence of a mighty electric attraction with another unit charged negatively. You see that this ought to produce compounds in which every unit of affinity of every atom is connected with one and only with one other unit of another atom. This is, as you will see immediately, indeed, the modern chemical theory of quantivalence, comprising all the saturated compounds. The fact that even elementary substances, with few exceptions, have molecules composed of two atoms, makes it probable that even in these cases electric neutralisation is produced by the combination of two atoms, each charged with its electric equivalent, not by neutralisation of every single unit of affinity.

But I abstain from entering into mere specialities, as, for instance, the question of unsaturated compounds; perhaps I have gone already too far. I would not have dared to do it if I did not feel myself sheltered by the 
authority of that great man who was guided by a nevererring instinct of truth. I thought that the best I could do for his memory was to recall to the minds of the men, by the energy and intelligence of whom chemistry has undergone its modern astonishing development, what important treasures of knowledge lie still hidden in the works of that wonderful genius. I am not sufficiently acquainted with chemistry to be confident that I have given the right interpretation, that interpretation which Faraday himself would have given perhaps, if he had known the law of chemical quantivalence, if he had had the experimental means of ascertaining how large the extent, how unexceptional the accuracy of his law really is; and if he had known the precise formulation of the law of energy applied to chemical work, and of the laws which determine the distribution of electric forces in space as well as in ponderable bodies transmitting electric current or forming condensers. I shall consider my work of to-day well rewarded if $I$ have succeeded in kindling anew the interest of chemists for the electro-chemical part of their seience.

At the conclusion of the lecture Prof. Roscoe made the following remarks :-

"The pleasing duty now devolves upon me of proposing a vote of thanks to our distinguished friend for his interesting, suggestive, and most appropriate address.

"Prof. Helmholtz has shown us that Faraday's conception of electricity is in exact accordance with the most modern developments of this science. He has told us that although Faraday was unacquainted with the technical details of mathematics, all his conclusions are capable of the most exact mathematical expression, and that our great experimentalist possessed the spirit and thoughts characteristic of a truly mathematical mind. But our lecturer has gone further, for upon Faraday's well-known law of electrolysis he has founded a new electro-chemical theory, which reveals to us chemists, conclusions of the utmost importance. $\mathrm{He}$ tells us as the results of the application of the modern theory of electricity to Faraday's great experimental law, that the atom of every chemical element is always united with a definite unvarying quantity of electricity. Moreover-and this is most important-that this definite amount of electricity attached to each atom stands in close connection with the combining power of the atom which modern chemistry terms quantivalence. For if the amount of electricity belonging to the monad atom be taken as the unit, then that of the dyad atom is two, of the triad atom three, and so on.

"Hence then, thanks first to Faraday and now to Helmholtz, chemists have now a new and unlooked-for confirmation of one of their most important doctrines from the science of electricity.

"These, Ladies and Gentlemen, are indeed sufficient grounds for our claiming Prof. Helmholtz as a chemist, and justify me in requesting that he will allow his name to be placed on the list of Honorary Fellows of the Chemical Society.

"I have much pleasure in proposing a hearty vote of thanks to the Faraday Lecturer for the year."

This proposal was seconded by Prof. Tyndall.

\section{NOTES}

Mr. ClarenCE KING has resigned his position as Director of the Geological Survey of the United States. It has long been no secret that he wished to retire from an appointment which confined him chiefly to executive functions, left him with practically no time for independent scientific work, and hampered him in those mining and other financial operations in which be is understood to have large investments. In a letter dated the I 2 th ult., addressed to the President of the United States, he says that he believes he "can render more important service to science as an investigator than as the head of an executive bureau." All well-wishers to the cause of geology must hope that this belief will be fully justified; that the relief he obtains from official trammels will enable him once more to devote to geological research the energy and experience which have already borne such good fruit. His tenure of office in the Geological Survey has hardly been long enough to enable him fully to develop the plans he had sketched out for the vigorous prosecution of the Survey as a truly national undertaking, alike creditable to the scientific spirit of the Republic and important to the development of its industrial resources. But he will be held in honour. able remembrance as the first head of the National Survey, and as having taken a leading share in its initial organisation. It is reported that Mr. J. W. Powell, so long and well known for his work in the Rio Colorado basin, is to be the new director.

A WISH having been expressed by certain members of the Torquay Natural History Society to have a portrait of $\mathbf{M r}$. William Pengelly, F.R.S., \&c., and he having kindly consented to sit for the same, a committee has been formed for carrying the suggestion into effect. The portrait will, at Mr. Pengelly's request, be placed in the museum of the Society, Torquay. It was at first proposed to limit the list of subscribers to the members of the Torquay Natural History Society, but some members of the Devonshire Association, and other gentlemen, having expressed a wish to join in the work, it has been decided to make the contribution general. Subscriptions will be received by the hon. treasurer, Mr. Robert Kitson, Torquay Bank.

The Royal Academy of Sciences of Turin gives notice that from January r, I879, the new term for competition for the third Bressa Prize has begun, to which, according to the testator's will, scientific men and inventors of all nations will be admitted. A prize will therefore be given to the scientific author or inventor, whatever be his nationality, who during the years I 879-I882, " according to the judgment of the Royal Academy of Sciences of Turin, shall have made the most important and useful discovery, or published the most valuable work on physical and experimental science, natural history, mathematics, chemistry, physiology and pathology, as well as geology, history, geography and statistics." The term will be closed at the end of December, 1882. The value of the prize amounts to 12,000 Italian lire. The prize will in no case be given to any of the national members of the Academy of Turin, resident or non-resident.

THE Literary and Philosophical Society of Manchester has recently completed the first century of its existence. Dr. Angus Smith is writing a history of the Society since its foundation, which will be read at an early meeting, and no doubt published in its Proceedings.

WE are glad to learn that the appeal on behalf of G. M. Smerdon, who has done such good work as foreman of the Kent Cavern explorations, has resulted in a sum sufficient to purchase him an annuity of $10 l$.

THE results of appointing a totally inexperienced and unknown man to the head of the Registrar-General's department, just before the taking of the census, are already beginning to be felt. Complaints of mismanagement are rife-whole streets in London not served with the census-papers, and in many cases those which were delivered have not yet been collected, and run some risk of being utilised for fire-lighting purposes. Certainly the interests of the country would have been best served by appointing Dr. Farr to the post of Registrar-General until at least the census work had been completed. Dr. Farr's long experience would have been of immense service, and these useful statistics would have been collected in something like scientific method.

THERE was a desultory talk on the subject of Technical Education in the House of Commons the other night, on the motion 